\title{
Kewenangan MUI Pasca Terbitnya PP No. 31 Tahun 2019 Tentang Peraturan Pelaksanaan UU No. 33 Tahun 2014 Tentang Jaminan Produk Halal
}

\author{
Elfirda Ade Putri \\ Fakultas Hukum, Universitas Bhayangkara Jakarta Raya \\ Email: elfirdade.putri@gmail.com
}

Article info

Received: Oct 17, $2021 \quad$ Revised: Nop 17, 2021 Accepted: Nop 23, $2021 \quad$ Published: Dec 9, 2021

DOI: https://doi.org/10.31599/krtha.v15i2.792

Keywords : $\quad$ Competency, MUI, balal guarantee

Abstract : Halal certification is a written fatwa of the MUI which states the halalness of a product in accordance with Islamic law. This halal certificate is a requirement to include a halal label so that a product is suitable for consumption by Muslim consumers. Business actors must meet certain requirements and go through a series of processes that have been determined by the MUI to obtain a halal certificate. After obtaining a balal certificate, business actors obtain a halal label from the MUI to then be included on the product label. This halal certificate is only valid for a certain period of time and business actors must extend it to obtain halal certification for their products again. Whereas the problem arises when Law Number 8 of 1999 concerning Consumer Protection does not make halal certification and labeling a mandatory form for business actors, but is voluntary. Therefore, it can be said that halal certification and halal labeling do not have strong legal legitimacy, so they do not provide legal protection and certainty for halal food products for consumers.

Kata kunci : Kewenangan, MUI, jaminan halal

Abstrak : Sertifikasi halal adalah fatwa tertulis MUI yang menyatakan kehalalan suatu produk sesuai dengan syariat Islam. Sertifikat halal ini merupakan syarat untuk mencantumkan label halal sehingga suatu produk layak untuk dikonsumsi oleh konsumen muslim. Pelaku usaha harus memenuhi syarat tertentu dan melewati serangkaian proses yang telah ditetapkan oleh MUI untuk memperoleh sertifikat halal. Setelah memperoleh sertifikat halal, pelaku usaha memperoleh label halal dari MUI untuk kemudian dicantumkan pada label produknya. Sertifikat halal ini hanya berlaku untuk jangka waktu tertentu dan pelaku usaha harus melakukan perpanjangan untuk memperoleh sertifikasi kehalalan produknya kembali. Bahwa Permasalahan timbul ketika Undang-Undang Nomor 8 Tahun 1999 tentang Perlindungan Konsumen, tidak menjadikan sertifikasi dan labelisasi halalsebagai sebuah bentuk kewajiban (mandotary) bagi pelaku usaha, tetapi bersifat sukarela ( $v o$ luntary). Maka sertifikasi halal dan labelisasi halal dapat dikatakan belum mempunyai legitimasi hukum yang kuat, sehingga tidak memberikan perlindungan dan kepastian hukum produkpangan halal bagi konsumen. 


\section{PENDAHULUAN}

Isu tentang produk makanan dan minuman yang diharamkan dan berbahaya sedang mendapatkan perhatian masyarakat. Produk produk makanan instan, makanan cepat saji, restoran sampai jajanan pasar merupakan hal yang rawan dicemari oleh jenis makanan yang tidak halal baik dari segi bahan, maupun prosesnya. ${ }^{1}$ Tuntutan konsumen akan produk halal belakangan memang semakin kritis, mereka tidak sekedar menuntut produk yang higienis dan terjamin kandungan gizinya, tetapi bagi yang muslim, salah satu yang menjadi konsen mereka adalah juga kehalalannya ${ }^{2}$, label halal pun menjadi ketentuan makanan tersebut dapat dikonsumsi atau tidak. ${ }^{3}$

Sertifikasi halal adalah fatwa tertulis MUI yang menyatakan kehalalan suatu produk sesuai dengan syariat Islam. ${ }^{4}$ Sertifikat halal ini merupakan syarat untuk mencantumkan label halal sehingga suatu produk layak untuk dikonsumsi oleh konsumen muslim. Pelaku usaha harus memenuhi syarat tertentu dan melewati serangkaian proses yang telah ditetapkan oleh MUI untuk memperoleh sertifikat halal. Setelah memperoleh sertifikat halal, pelaku usaha memperoleh label halal dari MUI untuk kemudian dicantumkan pada label produknya. Sertifikat halal ini hanya berlaku untuk jangka waktu tertentu dan pelaku usaha harus melakukan perpanjangan untuk memperoleh sertifikasi kehalalan produknya kembali.

Sertifikat halal bertujuan untuk memberikan kepastian kehalalan suatu produk sehingga dapat menenteramkan batin yang mengkonsumsinya. ${ }^{5}$ Produk halal adalah produk yang memenuhi syarat kehalalan sesuai dengan syariat Islam, yaitu:

1. Tidak mengandung babi dan bahan yang berasal dari babi.

2. Tidak mengandung bahan-bahan yang diharamkan seperti bahan-bahan.

3. yang berasal dari organ manusia, darah, kotoran-kotoran dan lain sebagainya.

4. Semua bahan yang berasal dari hewan halal yang disembelih menurut tata cara syariat Islam.

5. Semua tempat penyimpanan, tempat penjualan, pengolahan dan transportasinya tidak boleh digunakan untuk babi. Jika pernah digunakan untuk babi barang yang

\footnotetext{
${ }^{1}$ Diana Candra Dewi, Rahasia Dibalik Makanan Haram, (Malang: U1IN-Malang, 2007), hlm. iii.

2 Adi Nur Rohman. (2019). The Existence of Maslahah Mursalah As The Basis of Islamic Law Development In Indonesia. Krtha Bhayangkara, 13(2). https://doi.org/10.31599/krtha.v13i2.9

${ }^{3}$ Suprihatin. (2020). Konsep Dasar Hukum Sebagai Norma Sosial (Studi Pada UU No 1 Tahun 1974 Dan Kompilasi Hukum Islam). Krtha Bhayangkara, 14(1). https://doi.org/10.31599/krtha.v14i1.49

${ }^{4}$ Wiku Adi sasmito, "Analisis Kebijakan Nasional MUI dan BPOM dalam Labeling Obat dan Makanan” dalam Studi Kasus: Analisis Kebijakan Kesehatan, Fakultas Kesehatan Masyarakat Universitas Indonesia, 2008, hlm. 14.

${ }^{5}$ Bagian Proyek Sarana Dan Prasarana Produk Halal Direktorat Jenderal Bimbingan. Masyarakat Islam Dan Penyelenggaraan Haji, Panduan Sertifikasi Halal, Jakarta: Departemen Agama RI, 2003, hlm.1
} 
tidak halal lainnya terlebih dahulu harus dibersihkan dengan tatacara yang diatur dalam syariat Islam.

6. Semua makanan dan minuman yang tidak mengandung khamar. ${ }^{6}$

Dengan kata lain produk halal adalah produk pangan, obat, kosmetika dan produk lain yang tidak mengandung unsur atau barang haram atau dilarang untuk dikonsumsi, digunakan atau dipakai umat Islam baik yang menyangkut bahan baku, bahan tambahan, bahan bantu dan bahan penolong lainnya termasuk bahan produksi yang diolah melalui proses rekayasa genetika dan iradiasi yang pengolahannya dilakukan sesuai dengan syariat Islam. $^{7}$

Setelah ditetapkan kehalalanya dalam rapat, dibuat keputusan fatwa untuk produkproduk yang diputuskan dalam rapat secara tertulis sebagaimana keputusan fatwa pada umumnya, selanjutnya dikeluarkan "Sertifikat Halal". Pemegang sertifikat halal MUI bertanggung jawab untuk memelihara kehalalan produk yang diproduksinya dan sertifikat halal tersebut tidak dapat dipindahtangankan. Sertifikat halal yang sudah berakhir masa berlakunya termasuk fotokopinya tidak boleh digunakan atau dipasang untuk maksudmaksud tertentu. ${ }^{8}$

Dalam pembentukan Undang-Undang No. 33 Tahun 2014 tentang Jaminan Produk Halal ini, banyak terjadi perdebatan. Proses yang sangat panjang seperti yang diberitakan di media massa, karena menyangkut kehidupan masyarakat Indonesia yang notabene mayoritas muslim bahwa masalah pemberian sertifikasi halal menuai banyak sorotan. UU Jaminan Produk Halal yang diusulkan atas inisiatif DPR sejak 2006 belum juga diselesaikan pembahasannya hingga akhir masa tugas periode 2009-2014. Hingga akhirnya disahkan oleh Presiden pada Tahun 2014 yang lalu.

LPPOM MUI sebagai lembaga non pemerintah yang selama ini menangani setifikasi halal, atau bisa dikatakan sebagai penjamin kehalalan suatu produk harus beradaptasi pasca lahirnya UU No. 33 Tahun 2014. Dalam Pasal diatas, telah jelas dipaparkan, bahwa badan penyelenggara Jaminan Produk Halal di sini dibentuk oleh pemerintah, pemerintah yang membentuk teamwork untuk pengesahan sertifikasi halal. Dalam Pasal lain, tentang pada bab II mengenai penyelenggara jaminan produk halal UU No.33 tahun 2014 Pasal 5 ayat

${ }^{6}$ Bagian Proyek Sarana dan Prasarana Produk Halal Direktorat Jenderal Bimbingan Masyarakat Islam dan Penyelenggaraan Haji, Panduan Sertifikasi Halal, Jakarta: Departemen Agama RI, 2003, hlm. 2.

${ }^{7}$ Bagian Proyek Sarana dan Prasarana Produk Halal Direktorat Jenderal Bimbingan Masyarakat Islam dan Penyelenggaraan Haji, Petunjuk Teknis Pedoman Sistem Produksi Halal Jakarta: Departemen Agama RI, 2003, hlm. 131.

${ }^{8}$ Bagian Proyek Sarana dan Prasarana Produk Halal Direktorat Jenderal Bimbingan Masyarakat Islam dan Penyelenggaraan Haji, Panduan Sertifikasi Halal, op. cit., hlm. 2. 
(1) bahwa penyelenggaraan jaminan produk halal dilakukan oleh pemerintah, dalam hal ini adalah Kementerian Agama.

Jika melihat penjelasan dari Pasal dalam UU JPH Huruf (a-j) sudah jelas bahwa dalam pelaksanaannya, perumusan dan penetapan Jaminan Produk Halal (JPH) dikerjakan oleh pemerintah, walaupun dalam Hal ini BPJPH belum terbentuk karena tugas, fungsi dan susunan organisasi BPJPH diatur dalam Peraturan Pemerintah. ${ }^{9}$ Pada ayat selanjutnyapun demikian, penetapan norma, standar, prosedur, dan kriteria jaminan produk halal, menerbitkan dan mencabut sertifikat halal dan label halal pada produk, melakukan registrasi sertifikasi halal pada produk luar negeri, melakukan sosialisasi, edukasi, dan publikasi produk halal, melakukan akreditasi terhadap Lembaga Produk Halal, melakukan registrasi auditor halal, melakukan pengawasan terhadap JPH, melakukan pembinaan auditor halal dan melakukan kerja sama dengan lembaga dalam dan luar negeri di bidang penyelenggaraan JPH, dalam hal ini semua keterangan yang ada pada Pasal 6 UU No. 33 Tahun 2014 tentang kewenangan BPJPH, menegaskan kewenangan BPJPH dalam mengurus sertifikasi halal, yang dalam hal ini belum ditentukan oleh pemerintah.

Di dalam Pasal 6 dan Pasal 7 UU No. 33 Tahun 2014 bahwa kerjasama BPJPH dengan kementerian dan/atau lembaga terkait sebagaimana dimaksud dalam Pasal 7 huruf (a) dilakukan sesuai dengan tugas dan fungsi kementerian dan/atau lembaga terkait. Pada Pasal selanjutnya, kerjasama BPJPH dengan LPH sebagaimana dimaksud dalam Pasal 7 huruf (b) dilakukan pemeriksaan dan/atau pengujian produk. Kerjasama BPJPH dengan MUI sebagaimana dimaksud dalam Pasal 7 huruf (c) dilakukan dalam bentuk:

a. Sertifikasi auditor halal;

b. Penetapan kehalalan produk dan

c. Akreditasi LPH.

Penetapan kehalalan produk sebagaimana dimaksud pada ayat (1) huruf (b) dikeluarkan MUI dalam bentuk Keputusan Penetapan Halal Produk. Ketentuan lebih lanjut mengenai kerjasama sebagaimana dimaksud dalam Pasal 7, Pasal 8, Pasal 9 dan Pasal 10 diatur dengan atau berdasarkan Peraturan Pemerintah. ${ }^{10}$ LPH yang dijelaskan pasal 12 UU JPH, pada pasal ini secara terang dijelaskan bahwa lembaga pemeriksa halal (LPH) dapat didirikan oleh masyarakat guna membantu kinerja BPJPH dalam pelaksanaan jaminan produk halal. Undang-undang ini membatasi ruang gerak MUI yang selama ini

${ }^{9}$ UU No. 33 Tahun 2014 Bab II, Pasal 5 ayat (5).

${ }^{10}$ UU No. 33 Tahun 2014, Pasal 7, 8, 9, 10. 
sudah berjalan. Di sisi lain memberikan ruang untuk masyarakat dalam membantu pemerintah. Peran serta masyarakat dalam JPH ini adalah perwujudan dari demokrasi yang telah dijalankan. Selain itu, peran serta masyarakat menegakkan nilai utama dari menjadikan negara ini bagian dari good governence. Lembaga penjamin halal dapat didirikan oleh siapapun dengan memenuhi kriteria yang tertera dalam pasal 13 UU No. 33 Tahun 2014.

Selain itu, LPH Harus diajukan oleh lembaga keagamaan Islam berbadan hukum. Melihat kasus di Indonesia tentunya banyak ormas yang berbadan hukum seperti NU dan Muhammadiyah, maka ormas tersebut dapat mendirikan LPH sebagaimana yang dimandatkan dalam undang-undang, agar tidak terjadinya bentrok antara ormas satu dengan ormas lainnya. Dengan penjelasan dalam Pasal ini, bahwa MUI tidak sepenuhnya sebagai lembaga pemeriksa halal sebagaimana sebelum undang-undang ini ada. Selanjutnya, tergantung kepada produsen makanan akan mengajukan pemeriksaan kehalalan produk ke lembaga manapun yang telah sejalan dengan undang-undang tersebut. Ini berarti produsen bebas menentukan pilihannya. Dengan berdirinya banyak lembaga pemeriksa halal (LPH) dalam UU No. 33 Tahun 2014, maka dengan ini akan terjadinya kompetisi yang sehat antar lembaga. Dengan adanya persaingan ini maka perlu adanya pengendalian mutu atau kualitas oleh pemerintah terhadap kinerja dan sumber daya manusia LPH. Dengan demikian proses sertifikasi halal berjalan dengan baik dan lancar, serta terbentuk nya pemerintahan yang transparan. Berdasarkan permasalahan tersebut dapat dirumuskan, beberapa masalah hukum yakni: 1) Bagaimana perspektif dari LPPOM MUI terhadap pembentukan Badan Penyelenggara Jaminan Produk Halal berdasarkan UU nomor 33 Tahun 2014? 2) Bagaimana fungsi dan kewenangan MUI pasca terbitnya (PP) No.31 Tahun 2019 tentang Peraturan Pelaksanaan dari UU No.33 Tahun 2014 tentang Jaminan Produk Halal (JPH).

\section{PEMBAHASAN}

\section{Fungsi dan Kewenangan LPPOM MUI dalam menetapkan Kehalalan Produk}

Pembentukan LPPOM-MUI didasarkan atas mandat dari Pemerintah/negara agar Majelis Ulama Indonesia berperan aktif dalam meredakan kasus lemak babi di Indonesia pada tahun 1988. LPPOM MUI didirikan pada tanggal 6 Januari 1989 untuk melakukan pemeriksaan dan sertifikasi halal. Untuk memperkuat posisi LPPOM MUI menjalankan fungsi sertifikasi halal, maka pada tahun 1996 ditandatangani Nota Kesepakatan Kerjasama antara Departemen Agama, Departemen Kesehatan dan MUI. Nota 
kesepakatan tersebut kemudian disusul dengan penerbitan Keputusan Menteri Agama (KMA) 518 Tahun 2001 dan KMA 519 Tahun 2001, yang menguatkan MUI sebagai lembaga sertifikasi halal serta melakukan pemeriksaan/audit, penetapan fatwa, dan menerbitkan sertifikat halal. ${ }^{11}$ Perindustrian, Kementerian Kelautan dan Perikanan, Kementerian Pariwisata dan Ekonomi Kreatif serta sejumlah perguruan Perguruan Tinggi di Indonesia antara lain Institut Pertanian Bogor (IPB), Universitas Muhammadiyah Dr. Hamka, Universitas Djuanda, UIN, Univeristas Wahid Hasyim Semarang, serta Universitas Muslimin Indonesia Makasar. Sedangkan kerjasama dengan lembaga telah terjalin dengan Badan Standarisasi Nasional (BSN), Kadin Indonesia Komite Timur Tengah, GS1 Indonesia, dan Research in Motion (Blackberry). Khusus dengan Badan POM, sertifikat halal MUI merupakan persyaratan dalam pencantuman label halal pada kemasan untuk produk yang beredar di Indonesia.

Sistem sertifikasi dan sistem jaminan halal yang dirancang serta diimplementasikan oleh LPPOM MUI telah pula diakui bahkan juga diadopsi oleh lembaga-lembaga sertifikasi halal luar negeri, yang kini mencapai 42 lembaga dari 25 negara.

Adapun wewenang LPPOM MUI berdasarkan Surat Keputusan tersebut sebagai berikut:

a. Bersama-sama dengan Dewan Pimpinan Majelis Ulama Indonesia melaksanakan pembentukan lembaga pengkajian pangan, obat-obatan dan kosmetika Majelis Ulama Indonesia Daerah.

b. Mengadakan rapat kerja nasional sekurangkurangnya dua tahun sekali.

c. Mengadakan kegiatan-kegiatan dalam rangka memasyarakatkan pangan halal kepada umat Islam.

d. Mengundang para ahli untuk mendiskusikan suatu masalah yang berhubungan dengan pangan, obat-obatan, dan kosmetika; (5) Memberikan teguran, peringatan, baik lisan maupun tertulis kepada produsen yang menyalahgunakan Sertifikat Halal yang telah diberikan Majelis Ulama Indonesia, termasuk produsen yang sengaja mengganti bahan produknya dari yang diajukan dalam proses sertifikasi. $^{12}$

\footnotetext{
11LPPOM-MUI, "Tentang LPPOM-MUI," dalam http://www.halalmui.org/mui14/index.php/main/go_to_section/130/1511/page/1, (diakses pada tanggal 18 Februari 2020, jam 18.00).

12 Ibid.
} 
Lembaga Pengkajian Pangan, Obat-obatan, dan Kosmetika Majelis Ulama Indonesia (LPPOM MUI) merupakan lembaga teknis dari Majelis Ulama Indonesia (MUI). Ruang lingkup usaha dari Lembaga Pengkajian Pangan Obat-obatan dan Kosmetika meliputi sertifikasi halal, pelatihan sistem jaminan halal, penelitian dan pengkajian ilmiah, sosialisasi dan promosi halal, dan pembinaan LPPOM daerah. Sertifikasi halal merupakan inti dari lembaga ini.

Sertifikasi Halal adalah suatu proses untuk memperoleh sertifikat halal melalui beberapa tahap untuk membuktikan bahwa bahan, proses produksi dan Sistem Jaminan Halal (SJH) memenuhi standar LPPOM-MUI. ${ }^{13}$

\section{Pembentukan Badan Penyelenggara Jaminan Produk Halal (BPPJH)}

Penyelenggaraan jaminan produk halal merupakan tanggung jawab negara, bahwa Pemerintah bertanggung jawab dalam menyelenggarakan Jaminan Produk Halal. ${ }^{14}$ Ketentuan tersebut, menjelaskan posisi dan peran pemerintah dalam perlindungan konsumen Muslim di Indonesia. Dengan pandangan bahwa, tanpa peran pemerintah, konsumen Muslim tidak mampu menunaikan kewajiban mengonsumsi produk halal, karena tidak mampu memvalidasi kehalalan produk. Jaminan mengenai Produk Halal hendaknya dilakukan sesuai dengan asas pelindungan, keadilan, kepastian hukum, akuntabilitas dan transparansi, efektivitas dan efisiensi, serta profesionalitas. Oleh karena itu, jaminan penyelenggaraan Produk Halal bertujuan memberikan kenyamanan, keamanan, keselamatan, dan kepastian ketersediaan Produk Halal bagi masyarakat dalam mengonsumsi dan menggunakan Produk, serta meningkatkan nilai tambah bagi Pelaku Usaha untuk memproduksi dan menjual Produk Halal.

Dalam rangka memberikan pelayanan publik, Pemerintah bertanggung jawab dalam menyelenggarakan JPH yang pelaksanaannya dilakukan oleh BPJPH. BPJPH dibentuk untuk melaksanakan penyelenggaraan Jaminan Produk Halal yang berkedudukan di bawah dan bertanggung jawab kepada Menteri Agama sebagaimana amanat UndangUndang Republik Indonesia Nomor 33 Tahun 2014 tentang Jaminan Produk Halal. Untuk penyelenggaraannya BPJPH dapat membentuk perwakilan di daerah, sepanjang jika diperlukan. ${ }^{15}$ BPJPH harus dibentuk paling lambat 3 (tiga) tahun terhitung sejak UU JPH diundangkan.

\footnotetext{
${ }^{13}$ LPPOM-MUI, Panduan Umum Sistem Jaminan Halal (Jakarta: LPPOM-MUI, 2008), hlm. 8.

14 Pasal 5 ayat 1 Undang-Undang Republik Indonesia Nomor 33 Tahun 2014 tentang Produk Jaminan Halal.

15 Zulham, Hukum Perlindungan Konsumen (Jakarta: Pranemedia Group, 2016), 120.
} 
Dalam penyelenggaraan Jaminan Produk Halal, BPJPH berwenang sebagai berikut: ${ }^{16}$

a. merumuskan dan menetapkan kebijakan JPH.

b. menetapkan norma, standar, prosedur, dan kriteria JPH.

c. menerbitkan dan mencabut Sertifikat Halal dan Label Halal pada Produk.

d. melakukan registrasi Sertifikat Halal pada Produk luar negeri;

e. melakukan sosialisasi, edukasi, dan publikasi Produk Halal.

f. melakukan akreditasi terhadap LPH.

g. melakukan registrasi Auditor Halal.

h. melakukan pengawasan terhadap JPH.

i. melakukan pembinaan Auditor Halal.

j. melakukan kerja sama dengan lembaga dalam dan luar negeri di bidang penyelenggaraan JPH.

Adapun dalam melaksanakan wewenangnya, BPJPH bekerja sama dengan:

a. Kementerian dan/atau lembaga terkait sesuai dengan tugas dan fungsi kementerian dan/atau lembaga tersebut.

b. Lembaga Pemeriksa Halal, untuk pemeriksaan dan/atau pengujian Produk.

c. Majelis Ulama Indonesia, dilakukan dalam bentuk sertifikasi Auditor Halal, penetapan kehalalan Produk; dan akreditasi LPH. ${ }^{17}$

Sertifikat halal adalah surat keterangan yang dikeluarkan oleh Majelis Ulama Indonesia (MUI) Pusat atau Propinsi tentang halalnya suatu produk makanan, minuman, obat-obatan dan kosmetika yang diproduksi oleh perusahaan setelah diteliti dan dinyatakan halal oleh LPPOM MUI. Pemegang otoritas menerbitkan setifikasi produk halal adalah MUI yang secara teknis ditangani oleh Lembaga Pengkajian Pangan, Obatobatan, dan Kosmetika (LPPOM).

Bagi konsumen, sertifikat halal memiliki beberapa fungsi. Pertama, terlindunginya kon- sumen muslim dari mengonsumsi pangan, obat- obatan dan kosmetika yang tidak halal; kedua, secara kejiwaan perasaan hati dan batin kon- sumen akan tenang; ketiga, mempertahankan jiwa dan raga dari keterpurukan akibat produk haram; dan keempat, akan memberikan kepas- tian dan perlindungan hukum.

Bagi produsen, sertifikat halal mempunyai beberapa peran penting. Pertama, sebagai pertanggungjawaban produsen kepada konsumen muslim, mengingat masalah halal

16 Pasal 6 Undang-undang Nomor 33 Tahun 2014 Tentang Jaminan Produk Halal.

17 Zulham, Hukum Perlindungan Konsumen, 121. 
merupakan bagian dari prinsip hidup muslim; kedua, meningkatkan kepercayaan dan kepuasan konsumen; ketiga, meningkatkan citra dan dayasaing perusahaan; dan keempat, sebagai alat pemasaran serta untuk memperluas area jaringan pemasaran; dan kelima, memberi keuntungan pada produsen dengan meningkatkan daya saing dan omzet produksi dan penjualan.

Sertifikasi juga harus menjangkau bahan baku, bahan tambahan maupun bahan penolongdalam bentuk "bukan kemasan" yang tidak diecerkan untuk bahan produk makanan, minuman, obat-obatan, kosmetik, dan produk lainnya yang beredar di masyarakat. Sertifikasi produk halal diberlakukan tidak hanya terhadapproduk dalam negeri tetapi juga produk luar negeri. Mengenai produk yang bersertifikat halal dari lembaga sertifikat luar negeri, perlu diperhatikan bahwa tidak semua standar luar negeri atau internasional dapat diterapkan di Indonesia karena di Indonesia batasan halal adalah yang paling ketat dan tidak dapat disimpangi. Misalnya di luar negeri babi yang telah berubah menjadi X dapat menjadi tidak diharamkan lagi, sedangkan di Indonesia babi yang telah mengalami perubahan apapun tetaplah diharamkan.

Terdapat sejumlah lembaga yang terlibat dalam persoalan halam haram suatu produk,yaitu Departemen Agama, Badan POM, dan MUI (Komisi Fatwa MUI, LPPOMMUI), Departemen Pertanian tergabung dalam Komite Halal Indo- nesia (KHI). Sertifikat halal berlaku dua tahun dan dapat diperbaharui untuk jangka waktu yang sama. Setiap pelaku usaha yang telah mendapatkan sertifikat halal terhadap produknya mencantumkan keterangan atau tulisan halal dan nomor sertifikat pada label setiap kemasan produk. Selama masa berlaku sertifikat halal tersebut, perusahaan harus dapat memberikan jaminan bahwa segala perubahan baik dari segi penggunaan bahan, pemasok, maupun tekonologi proses hanya dapat dilakukan dengan sepengetahuan LPPOM MUI yang menerbitkan sertifikat halal. Jaminan tersebut dituangkan dalam suatu sistem yang disebut Sistem Jaminan Halal (SJH). SJH dibuat oleh perusahaan berdasarkan buku panduan yang dikeluarkan oleh LPPOM MUI.

Pada awal kegiatan sertifikasi halal, terjadi dualisme sertifikat, yakni antara Sertifikat Halal MUI dengan Label Halal yang dikeluarkan izinnya oleh Ditjen Pengawasan Obat dan Makanan Departemen Kesehatan. Masalah ini akhirnya dapat diselesaikan dengan ditandatanganinya Piagam Kerjasama antara Departemen Kesehatan, Departemen Agama dan Majelis Ulama Indonesia pada tanggal 21 Juni 1996.

Sertifikat halal dan labelisasi halal merupakan dua kegiatan yang berbeda tetapi mem- punyai keterkaitan satu sama lain. Hasil dari kegiatan sertifikasi halal adalah 
diterbitkannya sertifikat halal, apabila produk yang dimaksudkan telah memenuhi ketentuan sebagai produk halal. Sertifikasi halal dilakukan oleh lembagayang mem-punyai otoritas untuk melaksanakan-nya. Tujuan akhir dari sertifikasi halal adalah adanya pengakuan secara legal formal bahwa produk yang dikeluarkan telah memenuhi ketentuan halal. Sedangkan labelisasi halal adalahpencantuman tulisan atau pernyataan halal pada kemasan produk untuk menunjukkan bahwa produk yang dimaksud berstatus sebagai produkhalal.

Begitu pula, setiap pelaku usaha yang akan mencantumkan label halal harus memiliki sertifikat halal terlebih dahulu. Tanpa sertifikathalal MUI, ijin pencantuman label halal tidak akan diberikan pemerintah. Sampai saat ini me-mang belum ada aturan yang menetapkan bentuk logo halal yang khas, sehingga pada umumnya produsen mencetak tulisan halal dalam huruf latin dan/arab dengan bentuk dan warna yang beragam. Akan tetapi beberapa produsen sudah mulai membuat logo halal dengan bentuklogo MUI dengan mencantumkan nomor sertifikat halal yang dimilikinya. Hal ini dirasakan lebih aman bagi konsumen karena masih banyakproduk yang beredar di pasaran yang mencantumkan label halal tanpa memiliki sertifikat halal MUI.

Peraturan yang bersifat teknis mengatur masalah pelabelan halal antara lain keputusan bersama Menteri Kesehatan dan Menteri Agama RI Nomor.427/Men.Kes/SKB/VIII/1985 (No. 68 Tahun 1985) tentang Pencantuman Tulisan Halal Pada Label Makanan. Jadi, jelas bahwa tulisan halal yang dibubuhkan pada label atau penandaan makanan produknya, dianggap oleh hukum bahwa produsen tersebut secara sah telah memenuhi prosedur sertifikasi produk halal dari LPPOM MUI. Namun bila ternyata terbukti sebaliknya, maka produsen dapat dituntut seca-ra hukum karena melakukan pembohongan publik. Di samping pelaku usaha harus bertanggung jawab atas label halal yang dicantumkan pada produknya, ia juga berkewajiban melapor kepada pihak pemerintah yang dalam hal ini Departemen Kesehatan RI. Prosedur ini sebagaimana yang diamanatkan oleh Keputusan Bersama Menteri Agama dan Menteri Kesehatan. Hal itu dimaksudkan untuk memudahkan melakukan pengawasan selanjutnya.

Kegiatan sertifikasi halal di Indonesia baru dilakukan sejak didirikan LPPOM MUI pada 1989, sedangkan ketentuan teknis tentang pelaksanaan labelisasi yang didasarkan atas hasil sertifikasi halal, baru dikeluarkan tahun 1996 yaitu Keputusan Menteri Kesehatan RI No. 82/ Menkes/SK/I/1996 tentang Pencantuman Tulisan "Halal” pada Label Makanan. Berkaitan dengan hal tersebut Kepmenkes RI Nomor 82/ 
Menkes/SK/I/1996, menyatakan tegas dalam Pasal 17. Berdasarkan keputusan tersebut, izin pencantuman label halal dikeluarkan oleh Di- rektorat Jenderal Pengawasan Obat dan Makanan Depkes RI (sekarang menjadi Badan Penga-was Obat dan Makanan/Badan POM) baik kedudukan, tugas, fungsi dan kewenangan berdasarkan sertifikat halal yang dikeluarkan oleh MUI.

Peraturan yang lebih tinggi yang menaungi atas ketentuan sertifikasi dan labelisasi halal antara lain Undang-Undang Nomor 18 Tahun 2012 tentang Pangan terutama Pasal 86 ayat (4) jo Pasal 95, 96, 97 dan Undang-Undang Nomor 8 Tahun 1999 tentang Perlindungan Konsumen (UUPK). Hal itu diperkokoh dengan UUPK pada Pasal 8 (h). Oleh karena itu, perusahaan yang akan melakukan pelabelan halal secara legalharus melakukan sertifikasi halal. Hal ini untuk menghindari adanya pernyataan halal yang tidak valid. Suatu perusahaan yang membuat pernyataan halal secara tidak valid dapat dikenakan sanksi sesuai dengan Pasal 62 ayat (1) UUPK, karena termasuk sebagai pelanggaran terhadap Pasal 8 (h) dari UU tersebut.

Proses sertifikasi halal yang dilakukan oleh MUI melalui LPPOM MUI dan Komisi Fatwa ini sudah melalui tahapan kontruksi pikir yang merupakan keharusan untuk mengarahkan hukum kepada cita-cita yang diinginkan masya- rakat (dalam hal ini konsumen dan pelaku usaha). Meminjam istilah Rudolf Stamler inilah yang disebut dengan cita hukum. ${ }^{25}$ Cita hukum tersebut ialah Pokok-Pokok Pikiran yang terkandung dalam Pembukaan Undang-Undang Dasar 1945; cita hukum tersebut tidak lain ialah Pancasila. Selain itu Pancasila telah ditetapkan para pendiri negara Proklamasi ini sebaga Norma yang tertinggi dalam kehidupan kenegaraan rakyat Indonesia, sebagai Norma Dasar Negara (Staatsgrundnorm).${ }^{26}$ Cita hukum berfungsi sebagai "bintang pemandu" bagi tercapainya cita-cita masyarakat. Meski merupakan titik akhiryang tidak mungkin dicapai, namun cita hukum memberi manfaat karena ia yang berlaku, dan kepada cita hukum dapat mengarahkan hukum positif sebagai usaha mengatur tata kehidupan dengan sanksi pemaksa, menuju suatu yang adil. Oleh karena itu, menurut Stammler, keadilan ialah usaha atau tindakan mengarahkan hukum positif kepada cita hukum. Dengan demikian, maka hukum yang adil ialah hukum yang diarahkan oleh cita hukum untuk mencapai tujuan-tujuan masyarakat.

Menurut hemat penulis, hukum merupakan sebuah kehendak yuridis manusia. Hukum bekerja berdasarkan sistem, dan sistem hukum nasional yang dibangun tidak hanya menyangkut substansi hukum (legal substance), melain- kan juga struktur hukum (legal structure) dan budaya hukum (legal culture). Untuk menegakan supremasi hukum seperti 
yang dkehendaki UUD Negara RI Tahun 1945. Ketiga sistem hukum tersebut perlu dikembangkan secara simul-tan dan terpadu, karena terdapat interrelasiyang bersifat komplementer antara ketiganya dalam hubungan fungsional.

\section{Sistem Jaminan Halal}

Jaminan suatu produk halal memerlukan sistem yang memuat jaminan kehalalan, baik ditinjau dari sisi bahan baku dan turunannya maupun dari proses produksinya. Sistem harus mampu menjamin bahwa produk yang dikon- sumsi masyarakat adalah halal yang disertai lembaga penentu kehalalan suatu produk, adanya tanda/label produk yang halal dilihat seca- ra mudah oleh konsumen, dan sistem penga- wasan secara berkesinambungan agar tidak ter-jadi penyimpangan. Untuk inilah sangat diper- lukan adanya sistem jaminan halal oleh perusahaan.

Sistem Jaminan Halal (SJH) adalah suatu sistem yang dibuat dan dilaksanakan oleh perusahaan pemegang sertifikat halal dalam rangka menjamin kesinambungan proses produksi halal. Sistem ini dibuat sebagai bagian dari kebijakan suatu sistem yang berdiri sendiri. sehingga produk yang dihasilkan dapat dijamin kehalalannya, sesuai dengan aturan yang digariskan oleh LPPOM MUI.

SJH harus diuraikan secara tertulis dalam bentuk manual halal. Pertama, Pernyataan kebijakan perusahaan tentang halal (Halal Poli- cy); kedua, Panduan Halal (Halal Guidelines) dengan berlandaskan Standard Operating Procedure; ketiga, Sistem Manajemen Halal (Halal Management System); keempat, uraian Kritis Keharaman Produk (Haram Critical Control Point); dan Kelima, Sistem Audit Halal (InternalHalal Audit System). Dalam kaitan ini, perusahaan yang telah mensertifikatkan halal untuk produknya dituntut menyiapkan suatu sistemuntuk menjamin kesinambungan proses produksi halal secara konsisten, yang disebut sebagai sistem jaminan halal.

Suatu kasus di mana distributor tidak ha- nya menyalurkan dan menjual suatu produk tertentu melainkan juga melakukan repacking (pengemasan ulang) ataupun relabeling (pela belan ulang), maka proses audit harus tetap dilakukan di lokasi produsen asal. Audit yang dilakukan di lokasi pengemasan dan pelabelanulang saja tidak cukup untuk memenuhi persyaratan sertifikasi halal. Bagi produk impor prosedur ini tetap berlaku meskipun produk tersebut telah disertifikasi oleh lembaga sertifikasi negara asal yang diakui MUI. Audit ke produsen asal tidak perlu dilakukan hanya jika produk yang dikemas dan dilabel ulang telah disertifikasi oleh MUI. Kewajiban pelaku usaha (Pasal 7 
UUPK) untuk memenuhi hak-hak konsumen dalam setiap barang dan/atau jasa yang diproduksi dan diperdagangkan. ${ }^{30}$

Menurut Muslich, Kepala Bidang SJH, LPPOM MUI ${ }^{31}$ Pelaku usaha yang hendak mengajukan sertifikat halal produknya, disyaratkanmenyiapkan beberapa hal. Pertama, produsen menyiapkan suatu SJH; kedua, SJH tersebut harus didokumentasikan secara jelas dan rinci serta merupakan bagian dari kebijakan manajemen perusahaan; ketiga, dalam pelaksanaan- nya, SJH ini diuraikan dalam bentuk panduan halal (Halal Manua); keempat, produsen me- nyiapkan prosedur baku pelaksanaan (Standard Operating Prosedure) untuk mengawasi setiap proses yang kritis agar kehalalan produknya dapat terjamin; kelima, baik panduan halal maupun prosedur baku pelaksanaan yang disiapkan harus disosialisasikan dan diuji coba di lingkungan produsen, sehingga seluruh jajaran, dari mulai direksi sampai karyawan memahami betul cara memproduksi produk halal dan baik; keenam, produsen melakukan pemeriksaan intern (audit internal) serta mengevaluasi apakahSJH dilakukan sebagaiman mestinya; dan ke- tujuh, untuk melaksanakan huruf $\mathrm{f}$ tersebut, perusahaan harus mengangkat minimum se- orang Auditor Halal Internal yang beragama Islam dan berasal dari bagian yang terkait dengan produksi halal.

Selanjutnya, perusahaan mendaftar ke LPPOM MUI, dengan melengkapi persyaratan, seperti: Izin Usaha, Izin Depkes, KTP Pemilik dan mengisi Formulir. Verifikasi awal dilakukan oleh LPPOM MUI tentang analisa kelayakan mendapatkan sertifikat halal dan kesepakatan sertifikat halal. SJH dari produsen dimaksudkansebagai SJH yang diharapkan dari produsen se- cara mandiri setelah mendapatkan sertifikat halal. Dengan SJH ini diharapkan perusahaan dapat menghasilkan produk yang benar-benar terjamin kehalalannya. Oleh karena itu, perlu adanya komitmen dari seluruh bagian organisasimanajemen, dimulai dari pengadaan bahan ba- ku sampai distribusi pemasaran.

Sistem Organisasi Halal merupakan sistem organisasi yang bertanggungjawab dalam pelak-sanaan sistem jaminan halal. Dalam Sistem Or- ganisasi Halal ini diuraikan struktur organisasi yang terdiri atas perwakilan top management dan bidang-bidang terkait antara lain: quality assurance (QA), quality control (QC), purcha- sing (pembelian), research and development $(\mathrm{R} \& \mathrm{D}),{ }^{32}$ production, dan pergudangan. Masing- masing bidang tersebut dikoordinasikan oleh auditor halal internal.

Ditinjau dari segi tujuannya, penyusunan dan penerapan SJH adalah untuk menjaga ke- sinambungan proses produksi halal, sehingga produk yang dihasilkan dapat selalu dijamin keha-lalannya sesuai dengan ketentuan LPPOM MUI. Oleh karena itulah, maka ada beberpaprinsip yang harus ditegakkan dalam operasio- nal. Pertama, Maqashid 
al-syariah. Pelaksana- an SJH bagi perusahaan yang memiliki sertifikat halal MUI mempunyai maksud memelihara kesu-cian agama, akal/ pikiran, jiwa, keturunan, dan harta di samping loyalitas pada negara. Kedua,jujur. Perusahaan harus jujur menjelaskan se- mua bahan yang digunakan dan proses produksi yang dilakukan di perusahaan di dalam Manual SJH serta melakukan operasional produksi halal sehari-hari berdasarkan yang tertulis di dalam- nya. Ketiga, kepercayaan. LPPOM MUI membe- rikan kepercayaan kepada perusahaan untuk menyusun sendiri manual SJH-nya berdasarkan kondisi nyata internal perusahaan. Keempat,Sistematis. SJH didokumentasikan secara baik dan sistematis dalam bentuk Manual SJH dan arsip terkait agar bukti-bukti pelaksanaannya di lingkungan perusahaan mudah untuk ditelusuri. Kelima, disosialisasikan. Implementasi SJH ada-lah merupakan tanggungjawab bersama dari le-vel manajemen puncak sampai dengan karya- wan, sehingga SJH harus disosialisasikan denganbaik dan menyeluruh di lingkungan perusahaan.Keenam, keterlibatan key person.

Perusahaan melibatkan personal dalam jajaran manajemen untuk memelihara pelaksanaan SJH. Ketujuh, komitmen manajemen. Implementasi SJH di perusahaan dapat efektif dilaksanakan jika di- dukung penuh oleh top management. Manaje- men harus menyatakan secara tertulis komit- men halalnya dalam bentuk kebijakan halal.Kedelapan, pelimpahan wewenang. Manajemen memberikan wewenang proses produksi halal- nya kepada auditor halal internal, yakni staf atau beberapa staf internal perusahaan yang ditunjuk resmi oleh manajemen perusahaan se- bagai staf untuk mengkoordinasikan pelaksana- an SJH. Kesembilan, mampu telusur, bahwa se-tiap pelaksanaan fungsi produksi halal selaluada bukti dalam bentuk lembar kerja yang da- pat ditelusuri keterkaitannya. Kesepuluh, abso-lut. Semua bahan yang digunakan dalam proses produksi halal harus pasti kehalalannya. SJH ti- dak mengenal adanya status bahan yang berisi- ko rendah, menengah atau tinggi terhadap ke- halalan suatu produk) spesifik. Sistem harus da-pat mengidentifikasi setiap bahan secara spesi- fik merujuk pada pemasok, produsen, dan ne- gara asal. Ini berarti bahwa setiap kode spesifikuntuk satu bahan dengan satu status kehalalan.Aplikasi SJH bukannya tanpa problematika yangmenghadang.

Beberapa problem teknis yang memerlu- kan perhatian khusus program SJH adalah se- bagai berikut. Pertama, terbatasnya sumber daya manusia dan banyaknya kegiatan produksi yang yang cukup menyita perhatian. Oleh kare- na itu, sering muncul inisiatif dari beberapaperusahaan untuk mencoba mengintegrasikansistem jaminan halal ini dengan ISO; kedua,penggunaan bahan turunan hewan merupakan masalah yang yang sering masih menjadi gan- jalan dalam praktek sistem jaminan halal; ke- tiga, dukungan 
KRTHA BHAYANGKARA | Volume 15 Number 2, December 2021

maksimal sarana prasarana se- perti: laboratorium, transportasi dan dokumen-tasi; dan keempat, komitmen dari auditor baik auditor LPPOM MUI maupun Auditor Internal di perusahaan.

\section{Pengaturan dan Pemberian Jaminan Perlindungan dan Kepastian Hukum bagi Konsumen Muslim Berdasar UU No. 18 Tahun 2012 tentang Pangan}

Terdapat beberapa pasal dalam UU No. 18 Tahun 2012 tentang Pangan (UU Pangan) yang berkaitan dengan pengaturan kehalalan produk pangan, yaitu dalam Bab VIII Label dan Iklan Pangan. Pasal 97, ayat (1), (2) dan (3). Pasal 97 sebagai berikut:

1) Setiap orang yang memproduksi Pangan di dalam negeri untuk diperdagangkan wajib mencantumkan label di dalam dan/atau pada Kemasan Pangan.

2) Setiap Orang yang mengimpor pangan untuk diperdagangkan wajib mencantumkan label di dalam dan/atau pada Kemasan Pangan pada saat memasuki wilayah Negara Kesatuan Republik Indonesia.

3) Pencantuman label di dalam dan/atau pada Kemasan Pangan sebagaimana dimaksud pada ayat (1) dan ayat (2) ditulis atau dicetak dengan menggunakan bahasa Indonesia serta memuat paling sedikit keterangan mengenai:
a. nama produk;
b. daftar bahan yang digunakan;
c. berat bersih atau isi bersih;
d. nama dan alamat pihak yang mem-produksi atau mengimpor;
e. halal bagi yang dipersyaratkan;
f. tanggal dan kode produksi;
g. tanggal, bulan, dan tahun kedalu-warsa;
h. nomor izin edar bagi Pangan Olah-an; dan
i. asal usul bahan Pangan tertentu.

Dengan pencantuman halal pada label pangan, dianggap telah terjadi pernyataan dimaksud dan setiap orang yang membuat pernyataan tersebut bertanggungjawab atas kebenaran pernyataan tersebut. Menurut penulis penjelasan Pasal 97 ayat huruf e ini yang menyatakan cukup jelas te-rasa janggal atau aneh karena bertentangan de-ngan bunyi ayatnya sendiri. Pada ayat (1) diatas menentukan bahwa setiap orang yang memproduksi pangan di dalam negeri untuk diperdagangankan wajib mencantumkan label di dalam dan/atau pada Kemasan Pangan. Jadi pada intinya bahwa keterangan tentang halalwajib dicantumkan, akan tetapi dalam penje- lasan dinyatakan cukup jelas. 
Apalagi bahwa kewajiban ini baru berlaku apabila si pro- dusen ingin menyatakan bahwa produknya halal.

Keanehan kedua adalah kebenaran pernya- taan halal walaupun tanggung jawab si pelaku usaha, akan tetapi tidak ada kewajiban untuk diperiksakan dulu kehalalannya oleh lembagayang berwenang, jadi seakan-akan kehalalan hanya ditentukan oleh produsen, bagi yang tidak mempercayainya, silahkan buktikan kebenarannya.

\section{KESIMPULAN}

Bahwa Sertifikasi Halal yang (selama ini) telah dilakukan oleh Majelis Ulama Indonesia (MUI) melalui LPPOM MUI dan Komisi Fatwa. Adapun kegiatan Labelisasi Halal dikelola oleh Badan POM sudah sangat tepat dan memberikanjaminan perlindungan dan kepastian hukum produk pangan halal karena sudah melalui pro- ses yang panjang antara lain adanya sistem ja- minan halal (SJH) oleh perusahaan, audit oleh LPPOM dan Komisi fatwa.

Permasalahan timbul ketika Undang-Undang Nomor 8 Tahun 1999 tentang PerlindunganKonsumen, Undang-Undang Republik Indonesia Nomor 18 Tahun 2012 tentang Pangan dan Pe- raturan Pemerintah Republik Indonesia Nomor 69 Tahun 1999 tentang Label dan Iklan Pangan tidak menjadikan sertifikasi dan labelisasi halalsebagai sebuah bentuk kewajiban (mandotary) bagi pelaku usaha, tetapi bersifat sukarela (voluntary). Maka sertifikasi halal dan labelisasi halal dapat dikatakan belum mempunyai legitimasi hukum yang kuat, sehingga tidak membe- rikan perlindungan dan kepastian hukum produkpangan halal bagi konsumen.

\section{SARAN}

Rancangan Undang-Undang Jaminan Produk Halal (RUU JPH) yang sedang dibahas di DPR segera menjadi Undang-undang dan tetap memberikanotoritas kepada MUI melalui LPPOM MUI dan Ko-misi Fatwa yang mengeluarkan fatwa halal, atau dapat saja pemerintah yang mengelarkan sertifikat halal setelah mendapat rekomendasi fatwa halal dari MUI atas kehalalan suatu pro- duk pangan. Pemerintah berfungsi sebagai re- gulator dan pengawas dalam implementasi ke- tentuan undang-undang yang akan ditetapkan tersebut. Jangan sampai terjadi regulator, pe- laksana dan pengawas berada/oleh satu tangan, karena akan menimbulkan kerancuan danketidakpastian hukum. 
KRTHA BHAYANGKARA | Volume 15 Number 2, December 2021

\section{DAFTAR PUSTAKA}

\section{Buku}

Departemen Agama Republik Indonesia. Al Hikmah Al Quran dan Terjemahnya. Bandung: CV Penerbit Diponegoro. 2013.

Farih, Amin. Kemaslahatan dan Pembaharuan Hukum Islam (Semarang: Walisongo Press. 2008.

Emzir. Metodologi Penelitian Kualitatif. Jakarta: Raja Grafindo Persada. 2010.

Huda, Miftahul. Filsafat Hukum Islam. Ponorogo: STAIN Ponorogo Press. 2006.

Lembaga Pengkajian Pangan Obat-Obatan Dan Kosmetika Majelis Ulama Indonesia. Panduan Umum Sistem Jaminan Halal. Jakarta: LPPOM-MUI. 2008.

Romli. Studi Perbandingan Usul Fiqh. Yogyakarta: Pustaka Pelajar. 2014.

S, Burhanuddin. Pemikiran Hukum Perlindungan Konsumen dan Sertifikasi Halal. Malang: UIN Maliki Press. 2011.

Saleh, Abdul Mun im. Otoritas Maslahah dalam Madhab Shafi'i. Yogyakarta: Magnum Pustaka Utama. 2012.

Siroj, Malthuf. Paradigma Usul Fiqh: Negoisasi Konflik Antara Maslahah dan Nash. Yogyakarta: Pustaka Ilmu Group. 2013.

Soekanto, Soerjono. Pengantar Penelitian Hukum. Jakarta: UI-Press. 1986.

Subana, M. Dasar-Dasar Penelitian Ilmiah. Bandung: Pustaka Setia. 2005.

Suratmaputra, Ahmad Munif. Filsafat Hukum Islam Al-Ghazali. Jakarta: Pustaka Firdaus. 2002.

Syarifuddin, Amir. Usul Fiqh Jilid 2. Jakarta: Logos Wacana Ilmu. 1999.

Zein, Muhammad Ma shum. Ilmu Usul Fiqh. Jombang: Darul Hikmah. 2008.

Zulham. Hukum Perlindungan Konsumen. Jakarta: Prenadamedia Group. 2016.

\section{Perundang-undangan}

Undang-Undang Dasar Negara Republik Indonesia Tahun 1945. 
KRTHA BHAYANGKARA | Volume 15 Number 2, December 2021

Undang-Undang Nomor 33 Tahun 2014 Tentang Jaminan Produk Halal.

Undang-Undang Nomor 8 Tahun 1999 Tentang Perlindungan Konsumen.

\section{Internet, Skripsi dan Jurnal}

Rohman. Adi Nur. (2019). The Existence of Maslahah Mursalah As The Basis of Islamic Law Development In Indonesia. Krtha Bhayangkara, 13(2). https://doi.org/10.31599/krtha.v13i2.9

Suprihatin. (2020). Konsep Dasar Hukum Sebagai Norma Sosial (Studi Pada UU No 1 Tahun 1974 Dan Kompilasi Hukum Islam). Krtha Bhayangkara, 14(1). https://doi.org/10.31599/krtha.v14i1.49

LPPOM-MUI, “Tentang LPPOM-MUI," dalam http://www.halalmui.org/mui14/index.php/main/go_to_section/130/1511/pag e/1, (diakses pada tanggal 18 Februari 2020, jam 18.00). 